\title{
Hospital-acquired urinary tract infection: a case control study
}

\author{
LN Markovic-Denic ${ }^{1 *}$, B Mijovic $^{2}$, S Jankovic ${ }^{1}$ \\ From International Conference on Prevention \& Infection Control (ICPIC 2011) \\ Geneva, Switzerland. 29 June - 2 July 2011
}

\section{Introduction / objectives}

Hospital-acquired urinary tract infections (HAUTIs) are responsible for about $40 \%$ of all healthcare-associated infections. The aim of the study was to assess risk factors and microbiological aspects of HAUTI on six wards of a general regional hospital in Serbia.

\section{Methods}

A case-control study was nested within prospective cohort HAUTIs study conducted from January to December, 2007. Surveillance was performed on all patients admitted directly from the community to one of the study wards and whose hospital stay covered $72 \mathrm{~h}$ or more. The cases were patients with HAUTIs, identified using definition of the Centers for Disease Control and Prevention. Three controls were identified for each case, being chronologically the next three patients surveyed who did not develop HAUTI. The patients and controles were mached by sex and age $( \pm 5$ years $)$.

\section{Results}

Assessment of 8,467 patients during study period revealed HAUTI in 125 of these. The overall incidence rate of HAUTI was 14.8 cases/1000 admissions. The mean age (range) of cases and controls were 64.9 (18-85) and 65.2 (17-86), retrospectively. Multivariate logistic regression analysis showed that increasing length of urinary catheterization (odds ratio [OR], 13.22; 95\% CI, 3.36-51.91) and increasing length of hospitalisation (odds ratio [OR], 1.21; 95\% CI, 1.04-1.42) were independently associated with increased risk of HAUTIs. The most frequently isolated Gram-negative bacteria were Enterobacter, Klebsiella sp, Proteus mirabilis and Escherichia coli. Enterococcus sp was the most frequent Gram-positive bacteria.

Institute of Epidemiology, School of Medicine, University of Belgrade, Belgrade, Serbia

Full list of author information is available at the end of the article

\section{Conclusion}

The length of urinary catheterization and prolonged hospitalization were the most important risk factors of HAUTIs.

\section{Disclosure of interest}

None declared.

\section{Author details}

${ }^{1}$ Institute of Epidemiology, School of Medicine, University of Belgrade, Belgrade, Serbia. ${ }^{2}$ Institute of Public Health, Uzice, Serbia.

Published: 29 June 2011

doi:10.1186/1753-6561-5-S6-P201

Cite this article as: Markovic-Denic et al:: Hospital-acquired urinary tract infection: a case control study. BMC Proceedings 2011 5(Suppl 6):P201.

\footnotetext{
Submit your next manuscript to BioMed Central and take full advantage of:

- Convenient online submission

- Thorough peer review

- No space constraints or color figure charges

- Immediate publication on acceptance

- Inclusion in PubMed, CAS, Scopus and Google Scholar

- Research which is freely available for redistribution

Submit your manuscript at www.biomedcentral.com/submit
}

\section{() Biomed Central}

